This is an electronic reprint of the original article. This reprint may differ from the original in pagination and typographic detail.

Author(s): Haapanen, Mika; Lenihan, Helena; Mariani, Marco

Title: Government policy failure in public support for research and development

Year: $\quad 2014$

Version:

Please cite the original version:

Haapanen, M., Lenihan, H., \& Mariani, M. (2014). Government policy failure in public support for research and development. Policy studies, 35(6), 557-575. https://doi.org/10.1080/01442872.2014.971728

All material supplied via JYX is protected by copyright and other intellectual property rights, and duplication or sale of all or part of any of the repository collections is not permitted, except that material may be duplicated by you for your research use or educational purposes in electronic or print form. You must obtain permission for any other use. Electronic or print copies may not be offered, whether for sale or otherwise to anyone who is not an authorised user. 


\title{
Government Policy Failure in Public Support for Research and Development
}

\author{
Mika Haapanen, Helena Lenihan and Marco Mariani*
}

\begin{abstract}
Promoting Research and Development (R\&D) and innovative activity is a key element of the EU Lisbon Agenda and is seen as playing a central part in stimulating economic development. In this paper we argue that, even allowing for benevolent policymakers, informational asymmetries can lead to a misallocation of public support for R\&D, hence government policy failure, with the potential to exacerbate pre-existing market failures. Initially, we explore alternative allocation mechanisms for public support, which can help to minimize the scale of these government policy failures. Of these mechanisms (grants, tax credits, or allocation rules based on past performance), our results suggest that none is universally most efficient. Rather, the effectiveness of each allocation rule depends on the severity of financial constraints and on the level of innovative capabilities of the firms themselves.
\end{abstract}

JEL CODES: L16, O31, O32

Dr Mika Haapanen, School of Business and Economics, University of Jyväskylä, Jyväskylä, Finland. Email: mika.p.haapanen@jyu.fi

Prof. Helena Lenihan (Corresponding author), Department of Economics, Kemmy Business School, University of Limerick, Limerick, Ireland. Email:

helena.lenihan@ul.ie

Dr Marco Mariani, IRPET - Tuscany's Regional Institute for Economic Planning, Florence, Italy Email: marco.mariani@irpet.ie 


\section{Introduction}

Promoting Research and Development (R\&D) and innovative activity is seen as playing a central part in stimulating economic development (Fagerberg et al. 2006; Ramstad 2009; Becker and Pain 2008; Edquist 2011; Innovation Union 2011). Despite persistent skepticism about technology policy in certain academic and political circles, investment in R\&D is a major issue for Europe's long-term policy strategy (Ortega-Argiles et al. 2009). Moreover, considerable evidence shows that there is a positive link between government policy incentives for $R \& D$ and the extent of firms' R\&D investments: the additionality of public $R \& D$ support is often, though not always, positive (Meuleman and De Maeseneire 2012; Zúñiga-Vicente et al. 2013; Luukkonen 2000).

In the economic environment currently prevailing in most economies as a result of the financial crisis, many commentators are hailing the benefits of promoting $R \& D$ and innovation activity as a means to help economies to break the dire economic cycles and poor growth prospects faced by many (Wyckoff 2009; Bailey et al., 2011). Recent evidence also shows that access to public funding for innovation 'helps to counteract pro-cyclical trends in innovation investments' (Paunov 2011, p. 32).

Given this backdrop, many governments are investing sizably in R\&D policy interventions and instruments such as R\&D grants (Innovation Union 2011). In light of increasing government budget constraints, it is more important than ever that a sufficient rationale exists for government intervention with respect to such $R \& D$ policy interventions (with respect to market failure and recent evolutionary perspectives). It is equally important, as suggested in the current paper, to study issues of government policy failure (i.e. potential allocative failures resulting from the government's action) with respect to R\&D supports, an area of public policy where this argument is easily invoked but seldom analyzed by both academic and policymaking commentators to date. The current paper aims to begin to fill this gap in the literature, by incorporating government failure (and the deriving loss of social welfare) in a number of theoretical illustrations representing typical situations in R\&D policymaking. 
Even assuming a benevolent policymaker who only pursues public interest, informational asymmetries and incomplete information can obviously lead to misallocation of public support for $R \& D$, hence government policy failure, with the potential to exacerbate pre-existing market failures. Allowing for the presence of this failure, we compare the social costs and benefits of alternative policy instruments (e.g. grant subsidies and tax credits) and alternative subsidy allocation mechanisms (e.g. random, grandfathering principle), and analyze the situation where firms have different financial constraints or innovative capabilities.

Each of these situations has been already analyzed in the literature. Our original contribution is to review them by adopting and adding a government policy failure perspective. Thus, the current paper is a step in the direction of deepening the understanding of subsidy allocation processes, as invoked, for instance, in Blanes and Busom (2004) and in Takalo and Tanayama (2010).

The remainder of the paper is organized as follows. In the next section we discuss the rationale for government intervention in the market for $R \& D$, focusing on related market failures and on the concept of government policy failure. In the second section we bring the concept above in the context of a two-firm case, where both firms suffer from financial constraints but demonstrate differing abilities to produce technological spillovers to the benefit of society. By contrast, fourth section assumes that both firms are financially unconstrained. The fifth section considers the allocation of subsidies between firms with different costs of capital and innovative capabilities. In the sixth section we examine the policy insights stemming from the theoretical analysis, and conclusions end the paper. Throughout, we illustrate the effectiveness of various allocation mechanisms, which have been adopted in the past or which are suggested by other policy arenas.

\section{Market and Government Failures}

In general terms, market failure arises from failures in the areas of competition, presence of public goods, positive or negative externalities, incomplete markets, information failures or market disequilibrium (Glykou and Pitelis 2011; Stiglitz 2000). In terms of $R \& D$ and innovation, the main justification for public intervention 
resides in the lack of incentives for private agents to invest, as well as in their lack of means (Martin and Scott 2000).

The first problem, lack of incentives, can result from positive externalities of technological development activity and from the public-good characteristics of newly generated knowledge, both of which raise questions about the potential appropriability of private $R \& D$ efforts. As $R \& D$ is likely to generate spillovers, and might achieve results possessing public good characteristics, agents are not incentivized to perform as much $R \& D$ activity as would be socially optimal and desirable (Arrow 1962; Jones and Williams 1998). ${ }^{1}$ These issues are likely to provide the greatest disincentives when technologies are of a general-purpose nature (Bresnahan and Trajtenberg 1995) ${ }^{2}$.

The second problem, lack of means to invest, may arise due to information asymmetries in capital markets, exacerbated by the fact that $R \& D$ activity is typically human-capital-intensive, opaque and risky. As argued by Giordani and Zamparelli (2011), R\&D investment decisions are made while investors are faced with conditions of 'severe uncertainty'. On the one hand, potential financiers have less information than entrepreneurs about the intrinsic riskiness of, and expected returns from, a given $R \& D$ project. This asymmetry may lead to insufficient provision of capital and loans (if any at all) necessary to get a project started (Stiglitz and Weiss 1981). On the other hand, after the project's inception, an agency problem may arise as the financier is unable to control the entrepreneur's behavior nor ensure that the latter does not behave opportunistically.

1. Roper et al. (2004) provide an overview of the different mechanisms through which positive externalities of R\&D can occur, while Borrus and Stowsky (1997) provide estimates of private and social returns from R\&D activity. Specifically, Borrus and Stowsky (1997) estimate the private rates of return on investments in new technology to be between 20 to 30 percent in a variety of industries with social returns varying from 20 to 100 percent with an average of 50 percent (see also Mansfield et al. 1977).

2. The Arrowian argument has been criticized in light of a number of subsequent theoretical developments. A major point has been raised by industrial organisation scholars, who have shown that competition between firms may result in a duplication of $R \& D$ efforts and, therefore, in a total investment level which is above the socially optimal level (Fundenberg and Tirole 1987; Dasgupta 1988; D'Aspremont and Jaquemin 1988). This non-optimality happens in a patent race, where two firms struggle to be the first to obtain a monopoly: only the winner will see its R\&D investment rewarded by the patent, while the investment carried out by the loser cannot be recovered and represents a cost for society. 
In light of the above, the entrepreneur's inability to finance the $R \& D$ project with his/her own funds may be (mis)taken by the financier as evidence of the entrepreneur's low motivation and effort. Similarly, it may be seen as a sign of the entrepreneur's lack of confidence in the success of the project, resulting in insufficient external provision of resources (Holmström and Tirole 1997). Although information asymmetries can interfere with the good functioning of any capital market, they affect young and small enterprises particularly severely, as these enterprises (relative to their larger and older firm counterparts) lack track records, collaterals and reputation (Zúñiga-Vicente et al. 2013; Czarnitzki and Kraft 2006). Additionally, from the financier's viewpoint, the volume of finance required may not be worth undertaking a costly risk-assessment procedure (Peneder 2008).

Despite the importance of justifications for intervention in $R \& D$ markets linked to more strategic objectives (Metcalfe 1997), policy interventions are usually initiated to overcome or mitigate the negative effects of the above market failures. These policy interventions include direct funding, fiscal incentives, and capital market stimulation. The public agent changes the relative cost of innovation to favor promising projects or desirable technologies, either by reducing the marginal cost of capital or by raising the marginal rate of return on private $\mathrm{R} \& \mathrm{D}$ investment (Wu 2008; Hall and van Reenen 2000). The public agent's goal is to induce firms to invest more than they would have in the absence government support, and also to bridge the financing gap that concerns specific types of private agents; for example, young and small enterprises whose lack of finance can curtail - or indeed prevent - investment (Peneder 2008).

However, a number of potential failures in government action can inhibit the achievement of many of the above goals. This is the notion of government policy failure. Weimer and Vining (2005) distinguish 'passive government failure' (where government does not intervene to correct market failures so as to achieve Paretosuperior outcomes) from 'active government failure' (where government intervention leads to less efficient allocations than those that existed prior to the intervention). We may also think of real-world situations where failure is partial, due to the fact that government intervention improves the allocation but in an incomplete way.

In the current paper, we focus on active government policy failure. Some authors convey a pessimistic vision of such failure: for example, Kreuger (1990) argues that 
'economists have demonstrated an incredible naivete with regard to government behaviour [...]' (p. 21-22); similarly, Winston (2006, p. 3) argues that evidence over the past thirty years 'suggest[s] that welfare cost of government failure may be considerably greater than that of market failure'; while Nedergaard (2006, p. 398) warns that if market failures at the micro level are addressed by public intervention, it may encourage private economic agents to become potential rent-seekers in the political system and create government failure [...] resulting in further increase in market failures'.

As suggested by public choice theory, active failure may be caused by government officials who are not benevolent and behave in a self-interested way, as highlighted in the budget-maximizing model (Niskanen 1971) and the bureau-shaping model (Dunleavv 1991). More generally, however, government choices may be limited by political values, norms or processes that force government to reconcile choices among conflicting preferences (Dolfsma 2011). Values or norms such as 'fairness' or 'equity' may constrain governments' options; political processes may empower distortive, rent-seeking behaviors, resulting in the phenomena of corruption and capture (Aidt 2003; Winston 2006). However, Acemoglu and Verdier (2000) have suggested that there may be a trade-off between market and government failures; government intervention might somehow be "optimal" if market failure is relatively important and government failure (e.g. corruption) relatively rare.

On the other hand, even if policymakers are benevolent, government policy failure may arise due to lack of sufficient information to make the right decisions, which can hamper any serious industrial or R\&D policy targeting. Pack and Saggi (2006) list many issues regarding which policymakers must be knowledgeable in order to implement successful industrial policies; these issues relate to knowledge spillovers, learning, and the nature and extent of capital market spillovers. As policymakers are not omniscient, one could consider industrial and $R \& D$ policy to be overambitious. On the other hand, information constraints affect entrepreneurs as well as policymakers; in addition justifications for intervention are not clear-cut even in conventional areas of economic policy (Rodrik 2008). Starting from this viewpoint, Rodrik challenges the idea of industrial policy aimed at correcting distortions by means of first-best instruments. He puts forward a vision of industrial policy as a 
process of discovery, where the policymaker elicits information from the private sector and both engage in a process of strategic collaboration and coordination ' $[\ldots]$ with the aim of uncovering where the most significant bottlenecks are, designing the most effective interventions, periodically evaluating the outcomes, and learning from the mistakes being made in the process' (Rodrik 2008, p. 20). During this process, government must deal with limited information and control over private market responses to the public stimulus, and with the choice of intervention and allocation mechanisms.

As to private responses to $R \& D$ policy, recent developments in program evaluation literature are providing us with new insights. The majority of studies point to the positive impact associated with R\&D incentives (Toivanen 2006; Zúñiga-Vicente et al. 2013); however, findings in general are still rather mixed (García-Quevedo 2004), a key issue being what effects should be expected. According to traditional economic theory, effects may be expressed in terms of the additional inputs or outputs of a 'black-box' innovation process (David et al. 2000; Klette et al. 2000); see Cerulli (2010) for a recent review of the related applied econometric literature. According to more evolutionary, systemic and managerial views, additional effects should be sought in the form of 'softer' elements, such as learning or organizational behavior within the firm which raise the firm's innovation capability (e.g. Buisseret et al. 1995; Fier et al. 2006; Busom and Fernandez-Ribas 2008; Autio et al. 2008; Clarysse et al. 2009; Caloffi and Mariani 2011; Berggren and Elinder 2012). Beyond equilibria at the single-firm level, much work must be done to understand the positive or negative effects of R\&D programs in terms of broader general equilibrium (Klette et al. 2000; Lenihan 2011). With respect to control of private responses, governments have some opportunities to monitor the behavior of beneficiary firms during the process of policy implementation.

In addition, and perhaps more importantly, effort should be focused on designing programs where incentives to private $\mathrm{R} \& \mathrm{D}$ are delivered in an appropriate form, and are allocated according to the 'right' mechanisms. The issue of how to allocate R\&D incentives is underexplored in the literature (Fu et al. 2012). In practice, governments can adopt a wide range of indirect and direct support measures for R\&D (see e.g. Griffith 2000; David et al. 2000). Intellectual property rights legislation is the most 
obvious example of an indirect policy; direct policies include direct funding for R\&D (i.e. grants/subsidies), government $R \& D$ contracts, tax credits for $R \& D$ and, under particular circumstances, investment in human capital formation.

Here, our focus is on direct measures; of these, the most commonly used in OECD countries are R\&D loans or grants (Blanes and Busom 2004), which are expected to be effective particularly where potential for knowledge spillovers is significant (e.g. Spence 1984; Trajtenberg 2001). However, this type of policy instrument raises significant operational issues related to the size of the grant. Toivanen (2006, p. 74) notes that, 'An important insight derived from the simplest model of R\&D subsidies is that optimal subsidies are heterogeneous, i.e., they ought to vary from firm to firm and from project to project, and that the informational demands for designing optimal policies are potentially prohibitive.' Pack and Saggi (2006) emphasize a similar point: given full information, optimal subsidies would have to be non-uniform.

In practice, however, if subsidies are treated as uniform, a range of policies can be used. Subsidies could be treated as uniform across firms, with each firm receiving the same absolute value of subsidy if it meets certain eligibility criteria. This type of approach is exemplified by innovation voucher measures, which are directed at easing small firms' access to external knowledge in order to carry on or develop/expand their R\&D and innovation processes (Cornet et al. 2006; DG ENTR-Unit D2 2009).

Other alternatives relate to providing uniform unit-subsidies for $\mathrm{R} \& \mathrm{D}$, based either on the grandfathering principle - i.e., firms receive incentives based on pre-subsidy $R \& D$ levels (e.g., tax credits) - or on a simple per-unit basis where the level of subsidy is proportional to proposed expenditure on $R \& D$ (e.g., R\&D grants). This latter option is by far the most commonly employed in European countries, and may respond to more or less selective procedures based on policymakers' assessment of the quality and potential of R\&D projects (Takalo et al. 2013; Huergo and Trenado 2010). R\&D grants have the advantage of directly tackling market failures that prevent firms from performing $R \& D$, but also leave room for moral hazard on the part of the firm. Additionally, they may give rise to arbitrary decisions by government and possible government policy failures. A tax credit system for $R \& D$ is preferred by some authors and policymakers; because it requires no discretion and (ex-ante) involvement by government or bureaucracy, it can benefit all businesses that have incurred eligible 
R\&D expenditures (Griffith 2000). Although tax credits may provide a stimulus to overall R\&D activity, some authors have stressed that they are less suitable than grants to address the sources of market failure (e.g. lack of capital to be invested, Czarntzki et al. 2011); in addition, they are likely to encourage firms to undertake $R \& D$ activities resulting in short-term revenues, rather than projects with high rates of social return or long-term exploratory activities (Hall and van Reenen 2000).

Finally, distribution mechanisms, including auction-based allocation mechanisms and random allocation of $R \& D$ support, are less politically acceptable and are difficult to implement. The auction approach has been developed by Giebe et al. (2006), among others; due to its peculiarities and complexity, space constraints prevent its analysis in the current paper.

Given our concern with government policy failure, we define it more explicitly by employing a partial equilibrium framework. Subsequently, we consider alternative assumptions about firms' financial constraints, costs of capital and innovative capabilities. Throughout, we discuss alternative allocation mechanisms for public support that can help minimize the scale of government policy failures.

\section{Defining Government Policy Failure with Financially Constrained Firms}

As do Howe and McFetridge (1976) and David et al. (2000), we posit that at each planning period firm $i$ faces a large set of potential R\&D investments, each of which has expected costs and benefits. Therefore, the projects may be compared and ranked in descending order on the basis of their internal rate of return. This ranking explains why the firm's marginal private returns (MPR) decreases as the firm increases its $\mathrm{R} \& \mathrm{D}$ investments.

The firm also faces marginal private costs (MPC) that varies with size of investment and reflects the opportunity cost of investing in R\&D. Following Hall (2002) and Hottenrott and Peters (2012), we assume that the firm draws on internal funds (IF) before resorting to external funding ${ }^{3}$; the cost of external capital is assumed to be higher than that of internal funds, as lenders require a risk premium in imperfect capital markets. Hence, the MPC schedule is first horizontal (at level $\mathrm{c}_{\text {int }}$ ) and then

3. This assumption is consistent with pecking-order theory in corporate finance (Myers and Majluf 1984). 
upward sloping (see Figure 1). ${ }^{4}$ For profit-maximizing firm $i$, the optimal level of R\&D investment $I_{i}^{*}$ occurs where marginal private return (MPR) equals marginal private cost (MPC).

\section{Figure 1}

Allocation of grant subsidies with perfect information

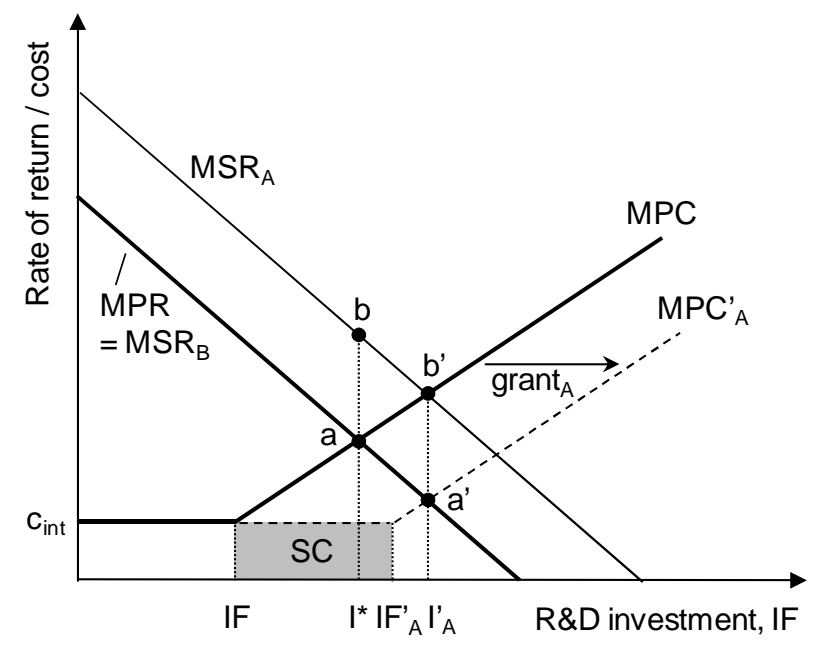

Suppose that the government considers subsidizing R\&D activity in two financially constrained $^{5}$ firms, A and B. While the economy contains many of these firms, the government considers subsidizing only two of them. ${ }^{6}$ As illustrated in Figure 1, it is assumed that R\&D investments of firm A generate additional social returns in the form of knowledge spillovers or externalities. Thus its marginal social return $\left(\mathrm{MSR}_{\mathrm{A}}\right)$ schedule lies above its marginal private return (MPR) schedule. Here, subscript indicates the firm; however, no subscript is used if a schedule or figure is the same for both firms. Here we assume that R\&D investments undertaken by firm B generate no social benefits. In this case, the $\mathrm{MSR}_{\mathrm{B}}$ and MPR schedules coincide. Apart from the difference in the marginal social returns, the firms are assumed to be identical. Both firms' private optima are given by point a, with the level of R\&D being undertaken given by $I^{*}$.

4. In the literature, these schedules are also called the marginal rate of return (MRR) and the marginal rate of cost (MRC) when no distinction is made between private and public returns (and costs).

5. By financial constraints we mean that in order to reach the private optimum, a firm will have to resort to external sources of funding.

6. We also assume for simplicity that subsidization of firm A does not affect the optimal investment of firm B (i.e., no displacement effect). 
We can usefully distinguish two policy scenarios here. First, assume that the government is perfectly aware of the scale of social benefits arising from each firm's $R \& D$ activity. As $R \& D$ undertaken by firm $B$ generates no social benefits (MPR = $\mathrm{MSR}_{\mathrm{B}}$ ), government does not wish to subsidize its R\&D investments. On the contrary, firm A's R\&D investment $I^{*}$ is below the socially optimal level: at the private optimum, the marginal social return is higher than the marginal cost. This is a classic illustration of market failure in the case of positive externalities (Nelson 1959; Arrow 1962).

With perfect information, the government can reduce the social welfare loss by giving a cash subsidy $\left(\right.$ grant $_{\mathrm{A}}$ ) to firm A. It is assumed that this amount of the grant is equal to the social benefit; thus it maximizes social welfare. ${ }^{7}$ The grant subsidy shifts its MPC curve right to $\mathrm{MPC}_{\mathrm{A}}^{\prime}$. At the new private optimum $\mathrm{a}^{\prime}$, firm A has increased its $R \& D$ investments to $I_{A}^{\prime}$, social benefits have increased by quadrangular $a b b^{\prime} a^{\prime}$, and market failure has been removed. Note, however, that reduction of market failure did not come without a price. The social (opportunity) costs of the grant are given by rectangle SC (grey area). That is, a (safe) return ( $\mathrm{c}_{\text {int }}$ ) for public subsidies could have been alternatively received from financial markets. ${ }^{8}$

Second, assume that the government's information set is less than perfect. This situation may arise when social benefits cannot be observed by all actors or are difficult to determine or estimate in advance. Information can also be asymmetric. Even if the firm knows the pattern of social benefits, it may choose not to reveal it; for instance, in an attempt to limit the outflow of spillovers (this could be the case for firm A which produces spillovers) or to ensure that it is not excluded by the set of beneficiary firms (this could be the case for firm B). In either situation, given a budget for supporting $\mathrm{R} \& \mathrm{D}$, the government faces an allocation decision in the context of incomplete information.

7. Note that the grant is independent of the firm's R\&D expenditures. Later we will consider cases where the subsidy is proportional to the firm's R\&D expenditures.

8. If we define by $\Delta \mathrm{I}_{\mathrm{i}}$ the increase in the R\&D investment for firm $i$ directly covered by the grant subsidy (i.e. $\mathrm{I}_{\mathrm{i}}-\mathrm{I}_{\mathrm{i}}$ ), then it is possible to identify a situation of additionality (or neutrality) if $\Delta \mathrm{I}_{\mathrm{i}}>$ subsidy $\left(=\Delta \mathrm{I}_{\mathrm{i}}\right)$ or a situation of crowding out if $\Delta \mathrm{I}_{\mathrm{i}}<$ subsidy. In Figure 1 the use of the grant subsidy on firm A results in partial crowding out. 
Suppose that the government is aware of the distribution of social benefits arising from $R \& D$ undertaken by firms $A$ and $B$, but does not know which of the firms' $R \& D$ creates positive social benefits. In light of this incomplete information, the government opts for a uniform (i.e. homogenous) R\&D grant subsidy ( $1 / 2$ grant for both $)^{9}$, as depicted in Figure 2 . In this instance, A and B will settle at b", both undertaking R\&D investment of I" . In the scenario depicted, a grant subsidy for firm A's R\&D investment will generate additional social benefits ( $a b b^{\prime \prime} a$ "), while a subsidy for firm B's R\&D investment will be completely wasteful. The cost of the grant subsidies is two rectangles $1 / 2 \mathrm{SC}$.

\section{Figure 2}

Allocation of grant subsidies with imperfect information

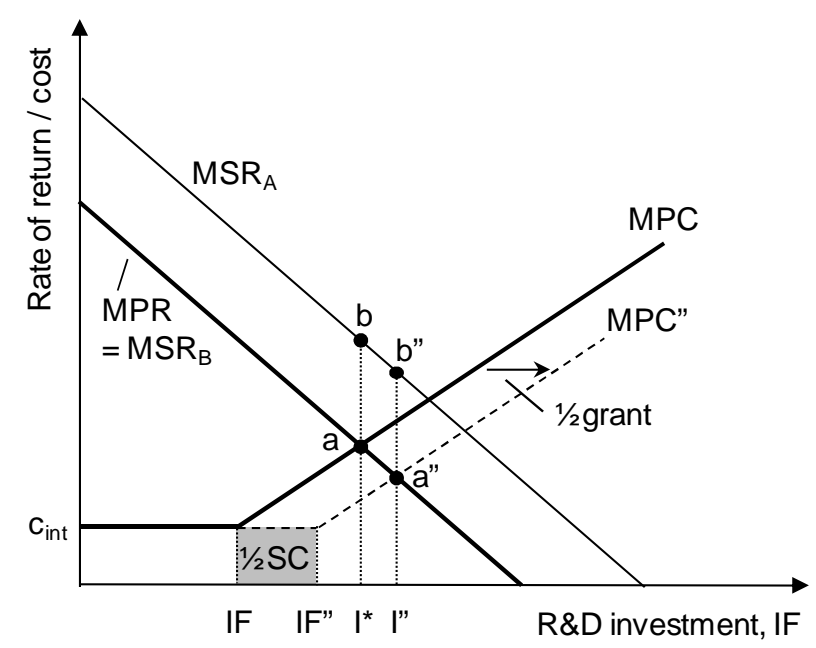

Government policy failure is defined as the loss of social welfare due to government's inefficient subsidy allocation. In the above example, government policy failure (GPF), resulting from incomplete information, can be calculated as a difference in the (increase in) social benefits between the two cases:

$$
\text { GPF }=\left(a b b^{\prime} a^{\prime}-S C\right)-\left[\left(a b b^{\prime \prime} a^{\prime \prime}-1 / 2 S C\right)+(0-1 / 2 S C)\right]=a b b^{\prime} a^{\prime}-a b b^{\prime \prime} a^{\prime \prime}=1 / 2 a b b^{\prime} a^{\prime}
$$

9. In practice such a government subsidy can be awarded as a voucher (providing a subsidy of equal value to each firm). This approach minimises transaction costs on the part of both government and firms, and may have the political advantage of 'fairness'. In the case of the Dutch innovation voucher scheme which adopts this approach, both of these advantages have been important to the scheme's take-up and success (Cornet et al. 2007; Cornet et al. 2006). This voucher-type government subsidy is now available in most European regions (DG ENTR-Unit D2 2009; Danish Innovation Policy 2010; Technopolis 2010). 
In this example, half of the social benefit is lost due to the failure of government to allocate subsidies correctly. The same result may be achieved if we assume that the grant subsidy $\mathrm{G}$ is randomly assigned to firm $\mathrm{A}$ or to firm $\mathrm{B}$, if both firms suffer from financing constraints and only firm $\mathrm{A}$ is able to produce positive social returns. We denote by $G_{A}=1$ the situation in which firm $A$ is randomly assigned the grant, which occurs with probability $P\left(G_{A}=1\right)=1 / 2$. Similarly, the situation in which the grant is randomly assigned to firm B (i.e., $G_{B}=1$ ) will occur with probability $P\left(G_{B}=1\right)=1-P\left(G_{A}=1\right)=1 / 2$. Expected government policy failure, $E(G P F)$, is then given by:

$$
\begin{aligned}
\mathrm{E}(\mathrm{GPF}) & =\left(a b b^{\prime} \mathrm{a}^{\prime}-\mathrm{SC}\right)-\left[\mathrm{P}\left(\mathrm{G}_{\mathrm{A}}=1\right) \cdot\left(a b b^{\prime} \mathrm{a}^{\prime}-\mathrm{SC}\right)+\mathrm{P}\left(\mathrm{G}_{\mathrm{B}}=1\right) \cdot(0-\mathrm{SC})\right] \\
& =\left(a b b^{\prime} \mathrm{a}^{\prime}-\mathrm{SC}\right)-\left[1 / 2\left(a b b^{\prime} a^{\prime}-\mathrm{SC}\right)+1 / 2(0-\mathrm{SC})\right] \\
& =a b b^{\prime} \mathrm{a}^{\prime}-1 / 2 a b b^{\prime} \mathrm{a}^{\prime}=1 / 2 a b b^{\prime} a^{\prime}
\end{aligned}
$$

This first example illustrates that government policy failure arises in any situation where subsidies are misaligned with the social benefits of firms' $R \& D$ activity. However, for simplicity, we have assumed that government's subsidy budget is sufficiently large to reach the social optimum. In a situation where government's subsidy budget is less than that, some market failure will remain. To minimize this market failure, a government with perfect information would allocate all of the subsidy to firm A (cf. Figure 1). With incomplete information, allocation of the subsidy across both firms would result in a further loss of social welfare as illustrated in Figure 2.

\section{Government Policy Failure with Financially Unconstrained Firms}

In the previous section, we assumed that firms are financially constrained. That is, they do not have sufficient internal funding for optimal $R \& D$ investment and therefore must resort to external funding. Suppose instead that firms are financially unconstrained at their initial private optimum (Figure 3). As before, firm A generates positive social returns but firm B does not. Assume that government tries to increase firm A's investments in $R \& D$, but falsely assumes that it is financially constrained. Figure 3 shows that the additional cash due to the grant subsidy does not change the 
optimal R\&D investment $I^{*}$ for an unconstrained firm; therefore, the full amount of the grant is wasted, regardless of its amount and to which firm it is given.

Figure 3

Grant subsidy when firms are financially unconstrained

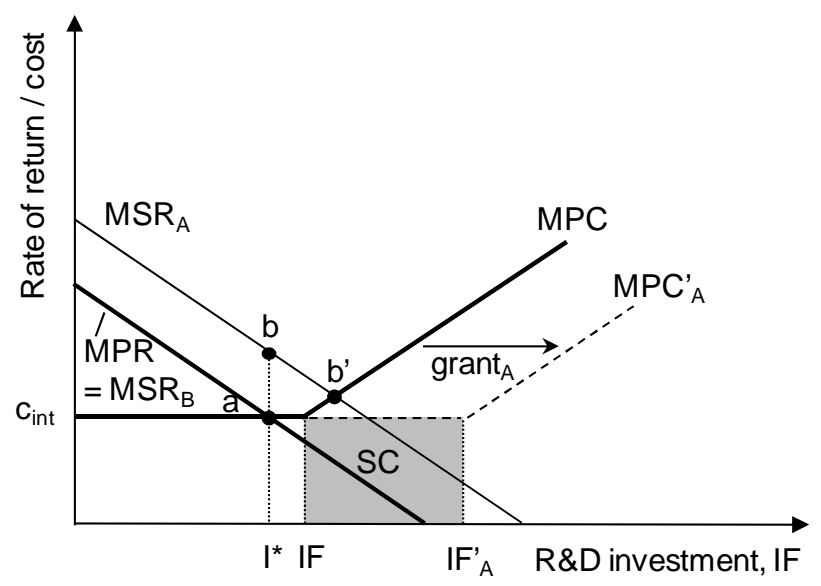

We now address the question of whether some other allocation mechanism could be used to increase (financially unconstrained) firm A's investment in R\&D and thus possibly lower the government policy failure. We begin by assuming that firm $\mathrm{A}$ is subsidized proportionally to its current expenditure on $R \& D$, for example, using a tax credit system. ${ }^{10}$ As illustrated in Figure 4, it is then possible to find a level of tax credit that would increase firm A's R\&D investment to $I_{A}^{\prime}$. The social benefits would increase by quadrangular $a b b^{\prime} a^{\prime}$, but at a high social cost relative to the benefits (see grey area SC). Marginal social returns should be greater (e.g. $\mathrm{MSR}_{\mathrm{C}}$ curve) if the illustrated tax credit is to meet the cost-benefit analysis criteria (e.g.acc'a' $\mathbf{a}^{\prime}$ ). If social benefits increase by less than the tax credit system costs, there is a clear failure in government action. As in the previous section, government policy failure can also arise if government does not know which of the two firms generates positive social benefits, or if it sets an incorrect magnitude for the tax credit.

10. See Appendix for an example that compares grant subsidy allocation to tax credit allocation when a firm is financially constrained. 


\section{Figure 4}

Tax credit when the firms are financially unconstrained

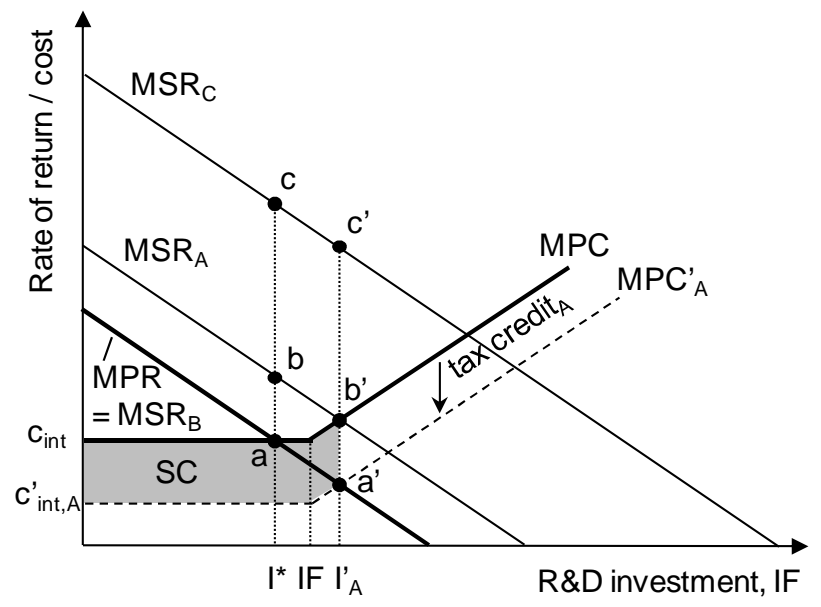

\section{Government Policy Failure with Different Costs of Capital and Innovative Capabilities}

In this section we acknowledge that government policy failure can also arise when subsidized firms differ vis-à-vis their financial constraints (i.e., marginal rates of cost) or innovative capabilities (marginal rates of return), but this information is partially or fully unknown to the government. As in Figures 1-2, we assume that firms are financially constrained, but on the contrary, both firms' $R \& D$ activity results in equal social returns that are higher than mere private returns.

In Figure 5, the government considers giving a grant subsidy to firms A and B. Both firms generate positive social returns and have an equal amount of internal funding, but they face different marginal costs for external funding: firm A's marginal cost of external funding is high, firm B's is low. If the government has perfect information, it will give a grant subsidy only to firm A: this choice will increase social benefits by aa' $\mathrm{c}^{\prime} \mathrm{c}$, which is greater than the social costs (SC). On the contrary, subsidizing firm B would result in an increase in social costs (SC) vis-à-vis social benefits (quadrangle $\left.\mathrm{bb}^{\prime} \mathrm{c}^{\prime} \mathrm{c}\right)$. 


\section{Figure 5}

Grant subsidy when firms' marginal private costs differ

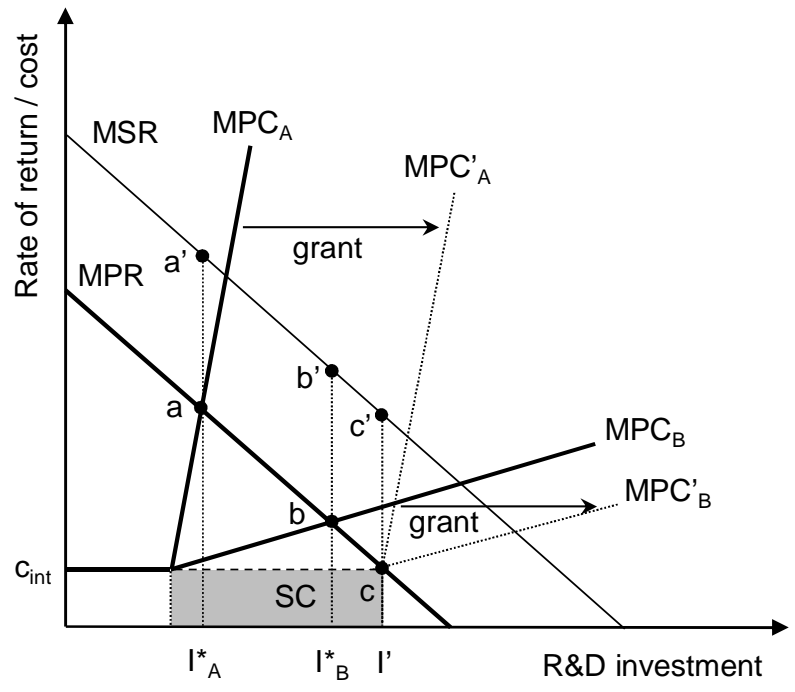

Alternatively, let's suppose that the government has imperfect information: it does not know which firm, A or B, is financially constrained. It looks at the average net gains from subsidies; given that they are higher than the average costs, it decides to subsidize both firms equally by splitting the grant in equal parts ( $1 / 2$ grant to both). However, the policy leads to government policy failure (GPF) as follows (Figure 2):

$$
\mathrm{GPF}=\left(a a^{\prime} c^{\prime} c-S C\right)-\left[1 / 2\left(a a^{\prime} c^{\prime} c-S C\right)+1 / 2\left(b b^{\prime} c^{\prime} c-S C\right)\right]=1 / 2 a a^{\prime} c^{\prime} c-1 / 2 b b^{\prime} c^{\prime} c
$$

where government policy failure relates to the difference between firms A and B in terms of the increase in social benefits generated by the subsidies.

Even when it has imperfect information as described above, government might be able to reduce policy failure if it knows the firms' pre-subsidy level of R\&D. Such information is useful if it positively correlates with each firm's optimal R\&D investment in the current period, thus revealing which firm is likely to face greater financial constraints. In Figure 6, it is assumed for simplicity that pre-subsidy levels of $R \& D$ are equal to optimal investment in the current program period. In this case government can allocate subsidies based on the inverse grandfathering principle, in which firm $i$ receives a proportion $K_{i}=1-I_{i}^{*} /\left(I_{A}^{*}+I_{B}^{*}\right)$ of the total grant available. 
That is, the subsidy is in inverse proportion to firms' pre-subsidy level of R\&D. ${ }^{11}$ Firm A, with a lower level of $\mathrm{R} \& \mathrm{D}$, receives more subsidies $\left(K_{A}=2 / 3\right)$, because it faces greater problems in finding external funding at a reasonable price. If the government strongly believes that pre-subsidy $R \& D$ reveals which firm is $A$ and which is $\mathrm{B}$, it could give the entire subsidy to the financially constrained firm A. However, if this belief is wrong the social benefits will be smaller than those produced by using the grandfathering principle.

\section{Figure 6}

Grant subsidy when firms' marginal private costs differ (inverse grandfathering)

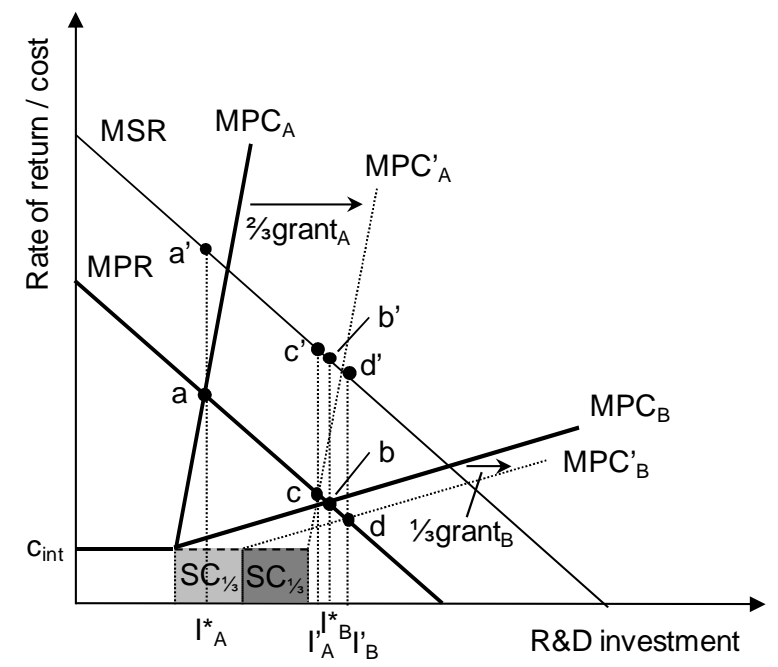

Figure 7 refers to a situation where the two firms differ in terms of innovative capabilities (i.e. marginal rates of return) but face equal financial constraints. If government is not aware of these differences and subsidies are delivered uniformly (same grant subsidy to both firms), a failure is very likely to arise. For example, in Figure 7, too large a grant subsidy is given to firm A: it would have chosen the same profit-maximizing $R \& D$ investment $I_{A}^{\prime}$ (point $a^{\prime}$ ) even with a smaller subsidy. In addition, since firm $B$ has higher innovative capabilities than firm A, a grant to firm B will increase social benefits at a higher rate (per its marginal rate of cost) than in the case of firm A. If a grant were given to two firms of type B, the increase in social benefits would be 2(bb'd'd). However, if A and B are equally subsidized, the resulting government policy failure would be:

11. Note that in reality the grant or tax credit is often directly proportional to the pre-grant level of $\mathrm{R} \& \mathrm{D}$, which suggests possible inefficiencies in the allocation of subsidies. 


$$
\begin{aligned}
\text { GPF } & =2\left(b b^{\prime} d^{\prime} d-S C\right)-\left[\left(b b^{\prime} d^{\prime} d-S C\right)+\left(a c c^{\prime} a^{\prime}-S C\right)\right] \\
& =\left(b b^{\prime} d^{\prime} d-S C\right)-\left(a c c^{\prime} a^{\prime}-S C\right)=b b^{\prime} d^{\prime} d-a c c^{\prime} a^{\prime}
\end{aligned}
$$

Note that firm B's (A's) social benefits bb'd'd ( acc'a') depend on the extent to which the subsidy generates increases in its investments and in social returns.

\section{Figure 7}

Grant subsidy when firms' innovative capabilities differ

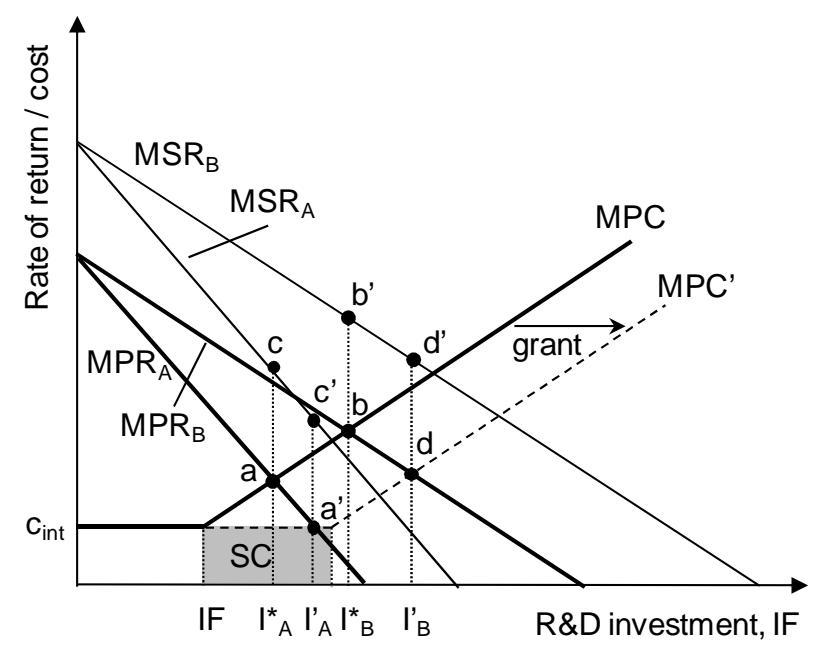

The government could also try to connect subsidy size to firms' pre-subsidy level of R\&D when innovative capabilities differ. However, in this case government should give a larger, not smaller, proportion of the subsidy to the firm with stronger innovative capabilities (B) as revealed by larger R\&D investments in the past (Figure 7). If the grandfathering principle is followed, firm $i$ would receive a proportion $K_{i}=I_{i}^{*} /\left(I_{A}^{*}+I_{B}^{*}\right)$ of the total grant subsidy available. However, firm B, with a higher level of $\mathrm{R} \& \mathrm{D}$, receives more subsidies because its innovation capabilities are (supposed to be) better.

\section{Policy Insights}

We have assumed that it is possible for government policy failure to derive only from informational constraints, and not from other problems characterizing bureaucracies (e.g., corruption and rent-seeking behavior of bureaucrats). Given this assumption, we have illustrated and analyzed the possibilities for active government policy failure when $\mathrm{R} \& \mathrm{D}$ subsidisable firms are heterogeneous, considering a variety of subsidy- 
allocation mechanisms. Firm heterogeneity may be unobservable by the government, and relates to: differing abilities of financially constrained (and unconstrained) firms (and their R\&D projects) to generate social returns higher than mere private returns associated with R\&D investments. In addition, our analysis has considered cases, where the severity of financing constraints differs across firms; or firms differ in terms of their innovative capabilities.

Our analysis has shown that government policy failure arises when all (or part of) the available subsidy funds are granted to financially constrained firms that do not generate spillovers. However, firms' ability to generate spillovers is a necessary but not a sufficient condition to merit the allocation of a subsidy to them. For example, if firms are financially unconstrained, there seems to be no rationale for R\&D grants. The full amount of grant subsidy is wastefully spent regardless of the firms' ability to generate spillovers. In this case, we have shown that a tax credit may be a more efficient allocation scheme. However, in a tax credit allocation scheme one must also ensure that social returns are high enough to offset the potentially higher social costs associated with tax credits (this cost is higher since it benefits all R\&D investments and firms, irrespective of heterogeneity and exposure to sources of market failure).

Firms may differ in terms of the severity of their financing constraints and/or their innovative capabilities. We have seen that government policy failure arises in a uniform-subsidy allocation when unobserved sources of heterogeneity exist. The failure is particularly likely if the available funds are granted to firms that i) suffer from relatively low financing constraints; or ii) have relatively low innovative capabilities.

Grandfathering allocation schemes (based on the pre-subsidy level of R\&D) can be used in an attempt to minimize the government policy failure. We have shown that when the innovative capabilities of firms differ, direct grandfathering is recommended. However, when the marginal costs differ inverse grandfathering should be used instead. Thus, government policy failure arises in the grandfathering allocation scheme when: i) higher subsidies are incorrectly granted to firms with fewer financial constraints; ii) higher subsidies are incorrectly granted to firms with lower innovative capabilities. 
Overall, it is not clear that either of these allocation mechanisms considered is clearly preferable in terms of minimizing government policy failure. With respect to $R \& D$ policy interventions and instruments, this finding challenges policymakers to carefully consider available options as they strive to support R\&D investments by firms. We have dealt with policy initiatives in this paper, which seek to reduce the cost of R\&D to the firm (Folster 1991; Stoneman 1991) and increase the pay-off of firm-level innovation. It is less easy to see how our static analysis can apply to policies designed to enhance the innovation potential of firms, such as collaborative R\&D programs (Peck 1986; Baumol 1992; Geroski 1992); or to policies that link firms' internal efforts with public R\&D carried out in the science base. The latter merits further investigation. What our analysis has the potential to achieve, however, is to encourage policymaking and academic communities to consider the range of R\&D policy choices to be made by government. It also highlights the need to explore new ways to ameliorate information asymmetries between firms and government with respect to R\&D investment decisions. Finally, our analysis highlights some of the true complexities in the R\&D policy allocation process.

\section{Conclusion}

Using a range of theoretical illustrations, we studied the notion of government policy failure in $R \& D$ policy in terms of allocation mechanisms for $R \& D$ funding at the micro (firm) level. This topic has been largely overlooked in the literature on government intervention with respect to R\&D policy. This is an opportune time to examine this concept, in view of increased interest (among policymakers and academics alike) in the potential of R\&D policy support to help economies not only to grow, but also to overcome economic ills resulting from the global financial crisis. It is particularly vital to limit government failure associated with $R \& D$ policy interventions in the current economic downturn; government budgets are more constrained than ever, so funding must be allocated as optimally as possible.

One of the key contributions of the current paper is its potential to stimulate further debate; such debate needs to happen from the perspective of both theory and policy.

The paper highlights the benefits of reverting to theoretical underpinnings of microeconomic concepts like government failure, which are frequently bandied about 
but seldom understood in a policy context. The discussion here is merely the first step in this type of analysis.

Relationships between firms and government frequently last over many years and involve numerous support packages; therefore, modeling longer-term relationships (possibly within a general equilibrium analysis model which includes a macrodynamic perspective) should be of interest to future research in this field. A more general equilibrium framework would facilitate exploration of issues such as those surrounding provision of $R \& D$ subsidies to firms in a dynamic setting; there is a whole other story to be explored beyond the partial equilibrium framework presented in the current paper. Much more work still has to be undertaken in order to understand the potential positive and negative effects (and externalities) of R\&D policy interventions and instruments in a broader general equilibrium setting.

\section{References}

Acemoglu, Daron and Thierry Verdier (2000). The choice between market failure and corruption, American Economic Review. 90: 194-211.

Aidt, Toke S. (2003). The economic analysis of corruption, The Economic Journal. 113: F632-F652.

Arrow, Kenneth (1962). Economic welfare and the allocation of resources for inventions. In Richard Nelson (eds.). The Rate and Direction of Inventive Activity, Princeton (pp. 609-626). Princeton NJ: University Press.

Autio, Erkko, Sami Kanninen and Robin Gustafsson (2008). First-and second-order additionality and learning outcomes in collaborative R\&D programs, Research Policy. 37: 59-76.

Bailey, David, Helena Lenihan, and Josep-Maria Arauzo-Carod (2011). Industrial Policy after the Crisis, Policy Studies. 32(4): 303-308.

Baumol, William J. (1992). Horizontal Collusion and Innovation, The Economic Journal. 102: 129-137.

Becker, Bettina and Nigel Pain (2008). What determines Industrial R\&D Expenditure in the UK? The Manchester School. 76: 66-87.

Berggren, Niclas and Mikael Elinder (2012). Is tolerance good or bad for growth? Public Choice. 150: 283-308. 
Blanes, J. Vicente and Isabel Busom (2004). Who participates in R\&D subsidy programs? The case of Spanish manufacturing firms, Research Policy. 33: 1459-1476.

Borrus, Michael and Jay Stowsky (1997). Technology Policy and Economic Growth, Working Paper 97, prepared for Evaluating Clinton-Gore Technology Initiative (working title) by Lewis M. Branscomb (ed.), Cambridge, MA, MIT Press.

Bresnahan, Timothy F. and Manuel Trajtenberg (1995). General purpose technologies, 'Engines of growth'? Journal of Econometrics. 65: 83-108.

Buiseret, Timothy, Hugh M Cameron and Luke Georghiou (1995). What differences does it make? Additionality in the public support of $R \& D$ in large firms, International Journal Of Technology Management. 10: 587-600.

Busom, Isabel and Andrea Fernandez-Ribas (2008). The impact of firm participation in R\&D programmes on R\&D partnerships, Research Policy. 37: 240-257.

Caloffi, A and Mariani, M (2011) 'Shaping regional policy responses: the design of innovation poles', Policy Studies. 32(4) 413-428

Cerulli, Giovanni (2010). Modelling and measuring the effect of public subsidies to business R\&D: A critical review of the econometric literature, The Economic Record. 86: 421-449.

Clarysse, Bart Mike Wright and Philippe Musta (2009). Behavioural additionality of R\&D subsidies: A learning perspective, Research Policy. 38: 1517-1533.

Cornet, Maarten, Björn Vroomen and Marc Van der Steeg (2006). Do innovation vouchers help SMEs to cross the bridge towards science? in: No $58 \mathrm{CBP}$ Discussion Paper CBP.

Cornet, Maarten, Björn Vroomen and Marc.Van der Steeg (2007). De effectiviteit van de innovatievoucher 2004 en 2005 output van bedrijven, edited by C.D. P. 140.

Czarnitzki, Dirk, Petr Hanel and Julio M. Rosa (2011). Evaluating the impact of R\&D tax credits on innovation: A microeconometric study on Canadian firms, Research Policy. 40: 217-229.

Czarnitzki, Dirk and Kornelius Kraft (2006). R\&D and Firm Performance in a Transition Economy, Kyklos. 59: 481-496.

Danish Innovation Policy (2010). Business R\&D and Innovation in Denmark, The Danish Ministry for Science, Technology and Innovation, May. 
Dasgupta, Partha (1988). Patents, priority and imitation or, the economics of races and waiting games, The Economic Journal. 98: 66-80.

D'Aspremont, Claude and Alexis Jacquemin (1988). Cooperative and non-cooperative R\&D in duopoly with spillovers, American Economic Review. 78: 11331137.

David, Paul A., Bronwyn H. Hall and Andrew A. Toole (2000). Is public R\&D to complement or substitute for private R\&D? A review of the Econometric Evidence, Research Policy. 29: 497-529.

DG ENTR-Unit D2 (2009). Availability and Focus on Innovation Voucher Schemes in European Regions, European Commission, Enterprise and Industry Directorate General.

Dolfsma, Wilfred (2011). Government Failure - Four Types. Journal of Economic Issues. 45: 593-604.

Edquist, Harald (2011). Can Investment in intangibles explain the Swedish productivity boom in the 1990s? The Review of Income and Wealth. 57: 658-682.

Fagerberg, Jan, David C. Mowery, and Richard R. Nelson (Eds.)(2006). The Oxford Handbook of Innovation. Oxford: Oxford University Press.

Fier, Andreas, Birgit Aschhoff and Heide Löhlein (2006). Behavioural Additionality of Public R\&D Funding in Germany, in: OECD (Ed.), Government $R \& D$ Funding and Company Behaviour: Measuring Behavioural Additionality. Paris: OECD.

Folster, Stefan (1991). The art of encouraging innovation, A new approach to Government innovation policy, The Industrial Institute for Economic and Social Research, Stockholm.

$\mathrm{Fu}$, Qiang, Jingfeng Lu and Yuanzhu Lu (2012). Incentivizing R\&D: Prize or subsidies? International. Journal of Industrial Organization. 30: 67-79.

Fundenberg, Drew and Jean Tirole (1987). Understanding dissipation: on the use of game theory in industrial organisation, American Economic Review. 77: 176183.

García-Quevedo, Jose (2004). Do Public Subsidies Complement Business R\&D? A Meta-Analysis of the Econometric Evidence, Kyklos. 57: 87-102.

Geroski, Paul A (1992). Vertical Relations Between Firms and Industrial Policy, The Economic Journal. 102: 138-147. 
Giebe, Thomas, Tim Grebe and Elmar Wolfstetter (2006). How to allocate R\&D (and other) subsidies: An experimentally tested policy recommendation, Research Policy,35: 1261-1272.

Giodani, Paolo E. and Luca Zamparelli (2011). On robust asymmetric equilibria in asymmetric R\&D-driven growth economies, Decisions Economics and Finance. 34: 67-84).

Glykou, I and Pitelis, C.N. (2011) 'On the political economy of the state, the publicprivate nexus and industrial policy' Policy Studies. 32(4), 461-478

Griffith, Rachel (2000). How important is business R \& D for economic growth and should the government subsidise it? Institute for Fiscal Studies briefing paper no 12. www.hm-treasury.gov.uk/media/5/9/255.pdf. Accessed 20th March 2013.

Hall, Bronwyn (2002). The financing of research and development, Oxford Review of Economic Policy. 18: 35-51.

Hall, Bronwyn and John van Reenen (2000). How effective are fiscal incentives for R\&D? A review of the evidence, Research Policy. 29: 449-469.

Holmström, Bengt and Jean Tirole (1997). Financial intermediation, loanable funds, and the real sector, Quarterly Journal of Economics. 112: 663-691.

Hottenrott, Hanna and Bettina Peters (2012). Innovative Capability and Financing Constraints for Innovation: More Money, More Innovation? Review of Economics and Statistics. 94: 1126-1142.

Howe, J. D. and Donald McFetridge (1976). The Determinants of R \& D Expenditures, The Canadian Journal of Economics. 9: 57-71.

Huergo, Elena and Mayte Trenado (2010). The Application for and the Awarding of Low- Interest Credits to Finance R\&D Projects, Review of Industrial Organization. 37: 237-259.

Innovation Union (2011). State of the Innovation Union, European Commission, Brussels. http://ec.europa.eu/research/innovation-union/pdf/state- of-theunion/2011/state_of_the_innovation_union_2011_brochure_en.pdf\#view=fit\& pagemode $=$ none. Accessed 15th August 2012.

Jones, Charles I. and John C. Williams. (1998). Measuring the social return to R\&D, The Quarterly Journal of Economics. 113: 1119-1135. 
Klette, Tor Jakob, Moen Jarle and Zvi Griliches (2000). Do subsidies to commercial R\&D reduce market failures? Microeconometric Evaluation Studies, Research Policy. 29: 471-495.

Kreuger, Anne O. (1990). Government Failures in Development, Journal of Economic Perspectives. Summer: 9-23.

Lenihan, Helena (2011). Enterprise policy evaluation: is there a 'new' way of doing it? Evaluation and Program Planning. 34: 323-332.

Luukkonen, Terttu (2000). Additionality of EU Framework Programmes, Research Policy. 29: 711-724.

Mansfield, Edwin, John Rapoport, Anthony Romeo, Samuel Wagner and George Beardsley (1977). Social and Private Rates of Return from Industrial Innovations, Quarterly Journal of Economics. 91: 221-240.

Martin, Stephen and John T. Scott (2000). The nature of innovation market failure and the design of public support for private innovation, Research Policy. 29: 437447.

Metcalfe, Stan (1997). Technology Systems and Technology Policy: in Daniele Archibugi and Jonathan Michie (eds.). An Evolutionary Framework. Technology, Globalisation and Economic Performance. Cambridge: Cambridge University Press.

Meuleman, Miguel and Wouter DeMaeseneire (2012). Do R\&D subsidies affect SMEs' access to external financing? Research Policy. 41: 580-591.

Myers, Stewart C. and Nicholas S. Majluf (1984). Corporate financing and investment decision when firms have information that investors do not have, Journal of Financial Economics. 13: 187-221.

Nedergaard, Peter (2006). Market failures and government failures: A theoretical model of the common agricultural policy, Public Choice. 127: 393-413.

Nelson, Richard R. (1959). The Simple Economics of Basic Scientific Research. Journal of Political Economy. 67: 297-306.

Niskanen, William A. (1971). Bureaucracy and Representative Government. Chicago: Aldine-Atherton.

Ortega-Argiles, Raquel, Marco Vivarelli and Peter Voigt (2009). R\&D in SMEs: a paradox? Small Business Economics. 33: 3-11.

Pack, Howard and Kamal Saggi (2006). Is there a case for Industrial Policy? A critical survey, The World Bank Research Observer. 21: 267-297. 
Paunov, Caroline (2011). The global crisis and firms' investments in innovation, Research Policy. 41: 24-35.

Peck, Merton (1986). Joint R\&D: the case of the microelectronic computer corporation, Research Policy. 15: 219-231.

Peneder, Michael (2008). The problem of private under-investment in innovation: A policy mind map, Technovation. 28: 518-530.

Ramstad, E (2009) 'Expanding innovation systems and policy-an organisational perspective' Policy Studies. 30(5), 533-553

Rodrik, Dani (2008). Industrial policy: Don't ask why, ask how, Middle East Development Journal. Demo Issue: 1-29.

Roper, Stephen, Nola Hewitt-Dundas and James Love (2004). An Ex Ante Evaluation Framework for the Regional Benefits of Publicly Supported R\&D Projects. Research Policy. 33: 487-509.

Spence. Michael (1984). Cost Reduction, Competition and Industry Performance, Econometrica.52: 101-121.

Stiglitz, Joseph (2000). Economics of the Public Sector: ( $3^{\text {rd }}$ edn.). W.W. Norton \& Company.

Stiglitz, Joseph E. and Andrew Weiss (1981). Credit rationing in markets with imperfect information, American Economic Review. 71: 393-410.

Stoneman, Paul (1991). The use of a levy/grant system as an alternative to tax based incentives for R\&D, Research Policy. 20: 195-201.

Takalo, Tuomas and Tanja Tanayama (2010). Adverse selection and financing of innovation: Is there a need for R\&D subsidies? Journal of Technology Transfer. 35: 16-41.

Takalo, Tuomas, Tanja Tanayama and Otto Toivanen (2013). Estimating the Benefits of Targeted R\&D Subsidies, Review of Economics and Statistics. doi: 10.1162/REST_a_00280.

Technopolis (2010). Policy Instruments for Regional Innovation: Innovation Vouchers. Belgium: Technopolis.

Toivanen, Otto (2006). Innovation and research policies: two case studies of R\&D subsidies, EIB papers. 11: 54-78.

Trajtenberg, Manuel (2001). R\&D Policy in Israel: An Overview and Reassessment: in Maryann P. Feldman and Albert N. Link, (eds.). Innovation Policy in the 
Knowledge- Based Economy, Boston: Kluwer Academic Publishers: 409454.

Weimer, David L. and Aidan Vining (2005). Policy Analysis: Concepts and Practice, ( $4^{\text {th }}$ edn). Upper Saddle River, NJ: Pearson Prentice Hall.

Winston, Clifford (2006). Government Failure versus market Failure: microeconomics Policy Research and Government Performance, AEIBrookings Joint Center for Regulatory Studies Washington, D.C. http://www.brookings.edu/views/papers/winston/20061003.pdf. Accessed 14 August 2012.

Witt, Ulrich (1996). Innovations, externalities and the problem of economic progress, Public Choice. 89: 113-130.

Wu, Yonghong (2008). State R\&D Tax Credits and High-Technology Establishments, Economic Development Quarterly. 22: 136-148.

Wyckoff, Andrew (2009). Innovating a recovery. OECD Observer. June, 273: 32-33. Zúñiga-Vicente, JoséÁngel, César Alonso-Borrego, Francisco Forcadell and José I. Galán (2013). Assessing the effect of public subsidies on firm R\&D investment: A survey, Journal of Economic Surveys. doi: 10.1111/j.14676419.2012.00738.x. 


\section{APPENDIX}

Both the tax credit and grant subsidy can be used as allocation mechanisms when firms are financially constrained. Hence, it is useful to compare their social costs when both allocation schemes generate same amount of additional social benefits. For example, the social costs of the proportional subsidy (tax credit) would have been much higher than those of a grant subsidy in Figure 1: the rectangle $\mathrm{I}_{\mathrm{A}}^{\prime}\left(\mathrm{b}^{\prime} \mathrm{a}^{\prime}\right)$ is larger in both height and width than the grey area BC. Figure A1 illustrates a case where tax credit is cheaper for the government. Notice, however, that the use of subsidies is questionable in both cases given that the social costs are larger than the social benefits (Figure A1). The amount of money spent on the tax credit can easily get high if firms' expenditure on $R \& D$ is large, and vice versa. Tax credit can be useful if the firm can get funding from capital markets at a reasonable price (i.e. MPC curve is relatively flat).

Figure A1

Grant and tax credit (tc) when firm is financially constrained

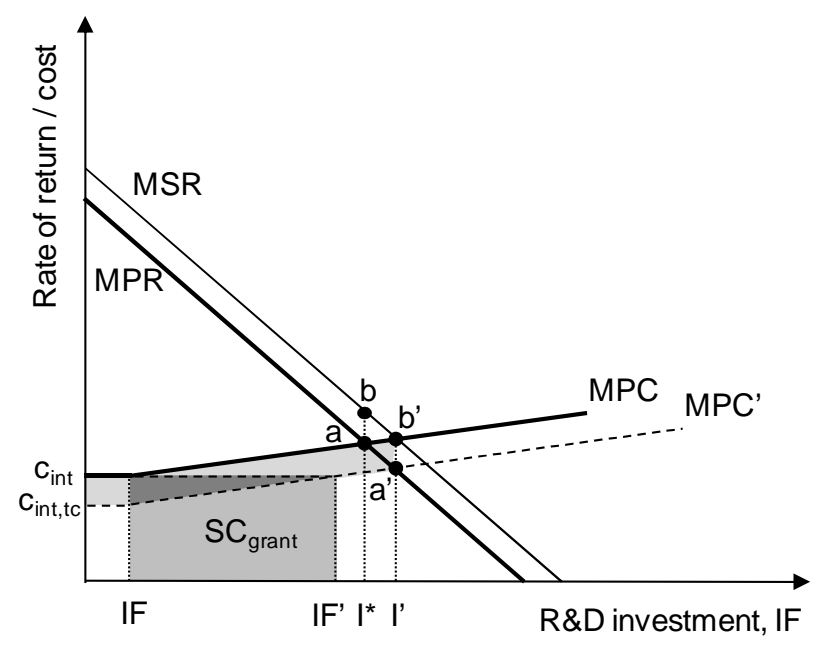

